\title{
Mexican Politeness: an Empirical Study on the Reasons Underlying/Motivating Practices to Construct Local Interpersonal Relationships
}

\author{
Gerrard Mugford \\ University of Guadalajara \\ Guadalajara, Mexico
}

\begin{abstract}
Fundamental concepts are all too often taken for granted in im/politeness research, especially since they are not always carefully and fully defined before researchers engage in confronting methodological issues. Definitions of im/politeness may reflect 'armchair' or intuitive approaches (Jucker and Staley 2017), which frequently ignore the sociocultural context within which relational work is performed. Following Larina's (2015) concept of communicative ethno-style, this study examines how Mexican im/politeness studies regularly build on classic ethnocentric decontextualised im/politeness approaches (e.g., Brown and Levinson 1987) and fail to understand laypeople's co-constructed discursive approaches (e.g. Watts 2003). This paper questions national and regional stereotypical approaches to understanding im/politeness practices and patterns. It examines the Mexican context and identifies how relational work is carried out at a localised level. Individual interactants can decide how they want to come across and which pragmatic resources they will employ when constructing, developing and maintaining interpersonal relationships. The paper is structured in the following way. First, I examine theoretical, discursive and contextually explanatory approaches to researching Spanish-language im/politeness in general. Then, by focusing on individual underlying social and linguistic behaviour, I scrutinise particular Mexican sociocultural politeness practices such as displaying confianza (familiar trust) and respeto (hierarchical respect) (Félix-Brasdefer 2008). In order to do so, I asked interview participants to assess their own motivations behind employing such im/politeness practices and provide experiences/instances of Mexican sociocultural practices. Finally, discussion focuses on how Mexican interactants co-construct interpersonal relations and how these are reflected through localised $\mathrm{im} /$ politeness patterns and practices
\end{abstract}

Keywords: Mexican understandings of im/politeness, choice, relational work, interpersonal language

\section{For citation:}

Mugford, Gerrard. 2020. Mexican politeness: an empirical study on the reasons underlying/motivating practices to construct local interpersonal relationships. Russian Journal of Linguistics 24 (1). 31-55. DOI: 10.22363/2687-0088-2020-24-1-31-55. 


\title{
Мексиканская вежливость: эмпирическое исследование причин использования коммуникативных практик для конструирования межличностных отношений
}

\author{
Герард Магфорд \\ Гвадалахарский университет \\ Гвадалахара, Мексика
}

\begin{abstract}
Аннотация
Фундаментальные понятия в исследовании не/вежливости часто принимаются как данность, хотя ученые, приступая к решению методологических проблем, не всегда дают им четкие и полные определения. Определения не/вежливости могут отражать далекие от реальности интуитивные подходы (Jucker \& Staley 2017), нередко игнорирующие социокультурный контекст, в котором осуществляется взаимодействие. Опираясь на понятие коммуникативного этностиля Т. В Лариной (Larina 2015), настоящая статья показывает, что исследования мексиканской не/вежливости в значительном числе случаев исходят из классических этноцентрических деконтекстуализированных концепций (например, Brown \& Levinson 1987) и не учитывают наивные дискурсивные подходы (например, Watts 2003). В данной статье подвергаются сомнению национальные и региональные стереотипные подходы к пониманию коммуникативных практик и моделей не/вежливости. В ней анализируется мексиканский контекст и выявляется, каким образом реляционные проблемы решаются на локальном уровне. Индивидуумы могут выбирать, какой образ себя они хотят представить и какие прагматические ресурсы хотят применить, конструируя, развивая и поддерживая межличностные отношения. Статья структурирована следующим образом. Сначала в ней анализируются теоретические, дискурсивные и контекстуальные объяснительные подходы к рассмотрению испаноязычной не/вежливости в целом. Затем исследуется индивидуальное социальное и языковое поведение, а также детально рассматриваются мексиканские социокультурные практики вежливости, такие как выражение доверия близким (confianza) и иерархического уважения (respeto) (Félix-Brasdefer 2008). С этой целью был проведен опрос, в котором участникам предлагалось оценить свои собственные мотивы использования таких практик не/вежливости и привести примеры мексиканских социокультурных практик. И, наконец, рассматривается, каким образом коммуниканты участвуют в конструировании межличностных отношений и как это отражается в мексиканских паттернах и практиках не/вежливости.
\end{abstract}

Ключевые слова: мексиканское понимание не/вежливости, выбор, реляционные практики, язык межличностного общения

\section{Для цитирования:}

Mugford, Gerrard. 2020. Mexican politeness: an empirical study on the reasons underlying/motivating practices to construct local interpersonal relationships. Russian Journal of Linguistics 24 (1). 31-55. DOI: 10.22363/2687-0088-2020-24-1-31-55.

\section{Introduction}

In an effort to categorise theoretical im/politeness models and to classify the ever-increasing number of $\mathrm{im} /$ politeness studies, researchers often structure different approaches in terms of first, second and third waves (Kádar 2017; Kádár 
and Haugh 2013). This step has proved useful in separating universalistic theoretical first-wave perceptions from situationally focused discursive secondwave understandings. Meanwhile, third-wave approaches attempt to interrelate theory and practice so that practical observation can be grounded within a theoretical framework (Kádar 2017). These lines of research, however, have either taken for granted, or grappled with, definitions of politeness, impoliteness, rudeness etc., especially since theoretical politeness models (e.g. Brown and Levinson 1987: Leech 1983) reflect ethnocentric and decontextualised perspectives (e.g., see Culpeper 2011a). On the other hand, as discussed by Culpeper (2011a), discursive approaches which examine situated and localised im/politeness instances often lack an explanatory framework from which it is difficult to draw any overall conclusions regarding im/politeness patterns and practices. As a result, third-wave approaches attempt to construct explanatory meanings from situated im/politeness practices.

Building on first-, second- and third-wave approaches to understanding politeness, I examine motivation and choice behind Spanish-language im/politeness practices (Fitch 2007) as interactants decide how they want to come across personally, interpersonally and socially. Personal projection of politeness, following Halliday's personal dimension, reflects 'the expression of our own personalities and personal feelings' (1973/1997: 36). The interpersonal aspect signals participant co-construction i.e. 'the achieving of meaning and action in interaction (Arundale 2010, 2078). Meanwhile, societal norms will dictate acceptable and appropriate politeness behaviour (Fraser 1990).

To understand communicative choices from the language users' perspective, I adopt a participative approach (Kádár and Haugh 2013), which helps identify personal, interpersonal and social patterns of behaviour, or what Larina (2015) terms communicative ethno-style. This position examines how laypeople employ $\mathrm{im} /$ politeness in establishing, maintaining, enhancing and undermining relationships (see also Spencer-Oatey 2008a, and section below on Second-wave Politeness). Given the predominantly Western cultural influence on im/politeness studies which are often seen to be ethnocentric, this study examines Latin American practices with a focus on how Mexican interactants engage in relational work. To this end, 32 middle-class Mexican professionals were interviewed regarding their perception of Spanish-language im/politeness communicative modes or speech events (Fitch 2007).

To examine the concept of politeness choices, I first relate first- and secondwave approaches to the study of Latin American politeness practices. Subsequently, I survey communicative choices that Mexican participants employ in order to express im/politeness. Then, the results of the interviews are presented and analysed so as to understand how these resources are used to achieve relational objectives. It should be stated from the outset that this is not a comparative study - other cultures may well adhere to the same practices. However, the objective of this study is to understand how Mexican interactants themselves understand their own practices. 


\section{Spanish-language politeness}

Whilst im/politeness studies in Spanish have largely compared and contrasted regional practices and are heavily influenced by universalistic 'Anglo-American models' (Márquez Reiter and Placencia 2005: 166), less research work has focused on relational dimensions that allow interactants to construct their own modes of behaviour. So rather than attempting to survey Spanish-language politeness research which has been amply and carefully carried out by Placencia and García (2007) and Félix-Brasdefer and Mugford (forthcoming), this work examines how choice is enacted in Spanish-language politeness practices. As seen in the ensuing examination of the three waves, Mexican politeness ought not to be discussed in 'scientific' terms but rather needs to be studied regarding how it is enacted and perceived by the interactants themselves.

\subsection{First-wave politeness}

First-wave politeness approaches in Spanish have mainly concentrated on studying speech acts (Marquez Reiter and Placencia 2005), mitigation (Czerwionka 2014; Maíz-Arévalo 2018) and terms of address (Mugford and Arias Moreno 2017). These communicative activities reflect the use of strategic and ritual politeness (Bernal 2018). First-wave approaches are theory-driven and are supported by practical examples as opposed to examining real-life practices and conventions, and consequently constructing a theoretical framework. Classic approaches towards politeness adopt a universalist approach and claim that politeness practices are similar across languages: 'The essential idea is this: interactional systematics are based largely on universal principles. But the application of the principles differs systematically across cultures, and within cultures across subcultures categories and groups' (Brown and Levinson 1987: 283).

Strategic politeness 'refers to acts intended to avoid face-threatening risks' (Bernal 2018, 133). Research into speech acts, for instance, has focused on how interactional objectives are achieved as seen through Ecuadorian refusals of offers (Placencia 2019) or Venezuelan and Argentinean invitation practices in terms of distance and power (Garcia 2008). Meanwhile, mitigation may be achieved through the use of diminutives (e.g. -ita in abuelita to show affection for grandmothers) and intensifiers (-isima as in buenísima to say 'very good') and consequently provides choices regarding how interactants wish to express emotion, affect, and closeness (Czerwionka 2014; Maíz-Arévalo 2018). With regards to terms of address, interactional choices take into consideration the addressee, context and communicative function. For instance, Mugford and Arias Moreno (2017) argue that the T/V pronoun distinction in Mexican Spanish cannot solely be understood by identifying predetermined social variables, e.g., power and respect, but needs to be understood through the concepts of autonomy and affiliation (Bravo 2008) (see also Scollon and Scollon 1995). Whilst hardly new, these concepts reflect an attempt to describe Spanish-language politeness in its own terms rather than solely 
rely on Anglo-American ethnocentric and decontextualised models (e.g. Brown and Levinson 1987: Leech 1983). Bravo (2008) argues that autonomy refers to how an interactant wants to portray him/herself and how he/she wants to be seen by others. Therefore, the choice of $\mathrm{T} / \mathrm{V}$ pronouns often reflects how an interactant positions $\mathrm{him} / \mathrm{herself}$ with respect to others.

Ritual politeness reflects everyday behavioural practice which 'occurs in meeting situations (which include acts of greeting at their initiation and saying goodbye at the end), and visit situations, including several acts that are performed by the host or the guest, according to their situational role in the encounter' (Bernal 2018: 266). Bernal's definition, which also appears to cover conventional politeness (for the distinction, see Terkourafi and Kádár 2017), would indicate that choice is determined by interpersonal relationships, situation and communicative purpose.

Whilst identified in first-wave politeness approaches, choices reflect communicative strategies rather than how interactants envisage their overall relationship with others and they reveal how relationships can be developed, maintained or disregarded. First-wave approaches provide a strong theoretical basis and framework with which to construct an understanding of politeness patterns and practices but often lack a situational setting in which to examine its actual use and practice.

\subsection{Second-wave politeness}

Second-wave politeness approaches in Spanish have focused on local contextual language use across conversational turns as opposed to examining single speech acts. Bernal (2018) discussed this in terms of valorising and discursive politeness. Valorising relates to relational work, e.g. rapport enhancement (Spencer-Oatey 2008a) whilst discursive reflects interactional and conversational expressions of politeness. Spencer-Oatey's work is especially relevant for secondwave Spanish-language politeness research as she argues that '[e]very language... provides a very wide range of linguistic options that can be used for managing face and sociality rights, and hence for managing rapport' (2008b: 21$)$. This means that each language needs to be studied as to how rapport is expressed interpersonally, situationally and contextually at both the individual and interactional levels. This can be achieved through ' $[\mathrm{t}]$ he discursive approach [which] is focused on the analysis of utterances in context and concerns itself with the judgements of individuals...' (Mills 2017: 15). Therefore, in trying to understand politeness practices and patterns, the individual interlocutors are the focus of attention.

Valorising politeness attempts 'to enhance the face of interlocutors, which can be achieved through acts such as directly complimenting them (their intelligence, their physical appearance) or things that belong to them' (Bernal 2008, 268). This can be carried out by engaging in face-boosting acts (FBAs) (Bayraktaroğlu 1991, 2001) and face enhancement (Sifianou 1995). In the Mexican context, FBAs are often expressed by demonstrating 'confianza - 'sense of deep familiarity' (FélixBrasdefer 2006, 2162); camaraderie - interpersonal intimacy (Félix-Brasdefer 
2008); afiliación - group affinity and loyalty (Curcó 2007); respeto — respect for the addressee's personal integrity (Curcó 2007); and reciprocidad - reciprocity (Curcó 2011)' (Mugford 2014: 108). These strategies aim to develop and consolidate interpersonal relationships by directly, often publicly and unreservedly bolstering the face(s) of other interactants.

Discursive politeness is revealed in conversational turns as interactional resources aid the co-construction of communicative meaning between participants. Discursive politeness 'utilizes the social function of showing interest for the interlocutors as competent speakers and of showing commitment with their discourses, ratifying them as valid narrators' (Bernal 2018: 136). In Spanishlanguage interaction this needs to be considered in terms of identity (Fant 1989), self-assertiveness (Fant 1989) and affiliation (Bravo 2008). The expression of identity, self-assertiveness and affiliation can be seen in such discursive patterns as the sequential organisation of talk and organisation of turn-taking patterns (Márquez Reiter and Placencia 2005). These practices can be specifically examined in backchannelling, interrupting, latching, overlapping, etc., as interactants establish their individuality and affiliation with other participants. For instance, whilst interrupting is socially proscribed, observation

in all but every formal meetings between strangers, suggests that Spaniards talk over each other (a) without necessarily 'interrupting' the speaker, (b) without any intention of impeding the beginning, middle or end of a message, but rather (c) most often simply to express an opinion for forcefully showing enthusiasm, passion and positive involvement in the conversation... (Hickey 2005: 318)

Therefore, interrupting practices in Spanish often allow participants to demonstrate their individuality, self-assuredness and identification with other interactants. A discursive approach can also be found in Fernández-Amaya (2019) who examines assertion and affiliation in terms of disagreement and impoliteness in a WhatsApp interaction within a Spanish family. She concludes that disagreement within the family should not necessarily be interpreted as face threatening.

Second-wave research provides rich data but the nature of its situational collection and analysis means that greater theoretical insights and implications may not be achieved and explored. As argued by Haugh (2007), the discursive approach runs the risk of abandoning politeness theory altogether and reducing its field to the study of interpersonal interaction.

\subsection{Third wave politeness}

Third-wave politeness interrelates communicative practice with theoretical understandings. It attempts to offer a contextually explanatory approach to understanding why participants behave in certain ways. Third-wave politeness understandings reject first-wave rationalistic theory-driven approaches which exemplify 'its principles with examples of observed language use' (Grundy 2000, 
186). Unlike second-wave approaches, it attempts to construct theory and explanation from situated politeness practices. A third-wave approach was adopted by Culpeper (2011b) in order to understand participants' understanding of impoliteness. He collected a mass of data including video recordings, written texts, corpus data and 100 informant reports and by also administering an impoliteness perception questionnaire. Based on findings from such data, Culpeper made firm scientific statements regarding impoliteness practices. However, as argued by Márquez Reiter and Placencia, '[t]he model of politeness that has had the greatest impact in the work of Hispanists, as in the work of other language specialists, is without doubt that of Brown and Levinson (1978, 1987)' (2005: 177). Consequently, Spanish-language politeness research work has focused on supporting theory with practical examples. However, there are exceptions and thirdwave approaches can be found, for instance, in Félix-Brasdefer who 'examined pragmatic variation in the context of service encounters in markets in Yucatán, Mexico' including 'the forms of address used to negotiate the request (stylistic level)' (2012: 44). He concludes that

... it is important to understand that requests for service in commercial (and non-commercial) settings are co-constructed and are the result of a collaborative process between buyer and seller to conduct transactions and to achieve meaning in social interaction. (Félix-Brasdefer 2012: 44)

Meanwhile, Márquez Reiter examined how Spanish speaking 'participants to service calls may navigate commercial constraints in their attempt to pursue their interactional agenda' (2019: 140). With both the call centre agent and the client negotiating high levels of ambiguity, Márquez Reiter (2019) sheds light on the minutiae of trying to achieve a sale and client resistance and the interactive resources that the participants employ to further their irreconcilable agendas.

\section{Mexican sociocultural values}

Mexican politeness practices reportedly focus more on the hearer rather than on the speaker. For instance, Grinsted (2000, in Curcó 2007) argued that 'Mexicans place the hearer in the center and the self on the periphery' (Curcó 2007: 113). This study examines and questions this assertion and examine the focus on Mexican politeness practices. Mexican politeness practices have been identified in secondwave approaches as a way of understanding politeness patterns and conduct. However, work still needs to be done on explaining the theoretical basis for these choices (a third-wave approach). In order to avoid privileging first-wave politeness methods which reflect researcher analysis, this paper takes a user-centred approach by asking the interactants themselves what is the rationale behind engaging in specific politeness practices and to highlight their perceptions and understandings of politeness practices. By examining real-life practices and conventions, this paper consequently aims to construct a subsequent theoretical framework rather than commencing with a theoretical framework or solely looking at politeness practices 
in a series of communicative situations. Since politeness conduct always involves choice, there must be a basis for interacting in a certain manner. In this way, everyday relational activity can be related to an overall framework of interpersonal understandings and communicative meanings.

If Mexican politeness as a concept cannot be described in universalistic terms as argued in classic politeness theory and only at a discursive level, it becomes important to examine how interactants themselves understand politeness practices and conduct. This position is supported by Locher and Larina who underscore the importance of the "evaluative and situated nature of concepts such as impoliteness or politeness' (2019: 875). Whilst Mexican politeness practices such as confianza, camaraderie, afiliación, respeto, and reciprocidad have been identified (e.g. FélixBrasdefer 2008; Mugford 2011, 2013, 2014), little follow-up work has specifically examined, illustrated and exemplified the phenomenon. A greater understanding can be achieved by constructing a theoretical framework around which their use highlights how interpersonal and transactional relationships are constructed, developed and are maintained in everyday Mexican Spanish politeness practices.

Mexican politeness practices reflect relational work as interactants establish, develop/enhance and play with interpersonal and transactional relationships. One way of achieving this is by engaging in such practices as mostrar confianza (show familiar trust) and mostrar respeto (demonstrate hierarchical respect) (FélixBrasdefer 2008). A specific politeness practice will depend on personal choice, interpersonal cooperation and social patterns of behaviour. Furthermore, politeness practices need to be related to specific speech communities and, therefore, the following terms relate specifically to the Guadalajara metropolitan area, which is located in western central Mexico, with a population of more than 5 million inhabitants.

When establishing relationships, participants will often focus on identifying and responding to the needs of others, which involves showing respect (respeto), catering to others' needs without being purposely asked (ser servicial) and recognising others' social status (dar su lugar). These actions acknowledge the addressee's social status and pay them the respect that they are seen to be worthy of.

In maintaining relationships, participants will often do good and help others without seeking or expecting any reciprocal action (hacer el bien) and are ready and willing to help when needed (acomedirse). Such activities reflect conformity to social norms and, at the same time, indicate a disinterested desire to respond to the needs of others.

To develop and enhance relationships, interactants frequently adopt a much more personal dimension by demonstrating very Mexican expressions of closeness, certainty and trust (mostrar confianza), and openly display a sense of fondness, affection and warmth towards others (mostrar cariño). Such manifestations may be apparent through face boosting acts as interactants publicly strengthen others' positive image and standing. 
The ludic dimension to interpersonal relationships can be seen through goodnatured teasing (echar carrilla) and joking/pulling someone's leg (vacilar). Whilst conversationally risky, the use of playful language, if successfully carried out, can further consolidate relationships as addressees do not feel that their face has been threatened or undermined.

These categories can be summarised as follows:

\begin{tabular}{|l|l|l|}
\hline Relational work & Mexican Spanish term & Translation to English \\
\hline Establish relationships & $\begin{array}{l}\text { Dar su lugar } \\
\text { Mostrar respeto }\end{array}$ & $\begin{array}{l}\text { Recognise social status } \\
\text { Show respect }\end{array}$ \\
\hline Maintain relationships & $\begin{array}{l}\text { Hacer el bien } \\
\text { Ser servicial } \\
\text { Acomedirse }\end{array}$ & $\begin{array}{l}\text { Do good to others } \\
\text { Be helpful and attentive } \\
\text { Be ready / willing to help }\end{array}$ \\
\hline $\begin{array}{l}\text { Develop/ enhance } \\
\text { relationships }\end{array}$ & Mostrar confianza, & Show trust \\
\hline Play within relationships & Mostrar cariño & Show affection \\
& Echar carrilla & Tease \\
& Pallar someone's leg \\
\hline
\end{tabular}

Figure 1: Mexican Spanish-language relational modes

Given the interpersonal, cooperative and social nature of Mexican politeness practices, interactants have the freedom to enact them in the way they want to (or not at all). How relational work is actually carried out depends on individual choice as interactants decide how they want to adhere to personal, interpersonal, cultural and social patterns of behaviour. Therefore, choice offers the participants communicative options regarding how they want to come across in each individual relationship.

\section{Data and Methodology}

To carry out the study, emails were sent out during October 2019 to 100 potential respondents inviting them to participate in the research which aims to understand the relational choices available to interactants when enacting politeness. The participants were requested within a month to complete a questionnaire which asked them whether they employed a particular politeness resource and, if so, why, with whom and where (see Appendix). In follow-up interviews, the participants were asked to recall and highlight specific politeness patterns and practices.

The politeness categories examined in this paper build on classification studies previously undertaken by Félix-Brasdefer (2008), Fitch (2007) and Mugford (2011) who have examined concepts such as respeto (respect), ser servicial (to be helpful and obliging) and confianza (sense of deep familiarity). This study centres on respondents' subjective perceptions of politeness practices in terms of personal motivation and choice. It adopts a self-report methodology as followed by Hernandez-López (2019) who examined 120 Airbnb reviews to understand users' emotional orientations. In the same vein, in this study, participants were asked whether they undertook a specific relational practice (Adherence to practice). 
Whilst it might be anticipated that interactants would automatically say yes, the underlying focus of the study is on understanding the motivation behind politeness practices. Consequently, participants were asked why they might engage in an individual practice (Relational focus) i.e. why use it and for what purpose. They were then asked with whom they used the practice (Focus of practice) and where (Context). The close similarity of the answers suggests that inferences and suppositions can be drawn from the results. Whilst these might not lead to solid conclusions, they do provide insights into Mexican politeness practices.

\subsection{Participants}

From the emails sent out, 32 respondents agreed to take part in the study. The profile of the participant in this study is that of a middle-class Mexican educational professional holding a university degree and aged between 25 and 40. (Further research may reveal whether social and education backgrounds are important factors in studying Mexican politeness practices.) The respondents are all personally known to the researcher through professional and social networks. They live in the Guadalajara metropolitan area, Mexico's second largest conurbation after Mexico City. The respondents were assured of a complete anonymity with their answers. At the same time, all of the answers were written in English and none of their answers have been modified or corrected in any way.

\subsection{Categories Analysed}

In order to analyse politeness practices, data are discussed in terms of the relational work in which interactants participate as they establish, maintain and develop / enhance relationships or how they engage in play within relationships. To understand how interactants establish relationships, a language of description highlights key concepts such as respect, assistance and concern for others as interactants show interest in recognising the status of others and supporting their wellbeing. As interlocutors seek to maintain relationships, important notions concern social harmony, comity and responsiveness as interactants try to be alert, aware and sensitive to the needs of others. To further develop and/or enhance rapport, interlocutors often pursue more meaningful interpersonal relationships which are often expressed through the concepts of solidarity, supportiveness and closeness. Finally, by engaging in play within relationships, participants demonstrate greater levels of trust and closeness, especially in terms of camaraderie, commonality and interpersonal cohesion.

\subsection{Questionnaire and interview design}

The questionnaire asks respondents to consider whether they adhere to nine Mexican relational practices which have been discussed above; dar su lugar (recognise others' social status); mostrar respeto (show respect); hacer el bien (help others without seeking reciprocal action), ser servicial (cater to others' needs), acomedirse (be ready and willing to help), mostrar confianza (demonstrate 
closeness, certainty and trust), mostrar cariño (display fondness, affection and warmth towards others), echar carrilla (good-natured teasing) and vacilar (joking/pulling someone's leg). Respondents were asked first of all whether they adhere to these practices and if so, what they consider the function of these relational practices to be. They were subsequently asked to say whom they used them with and in which situations or contexts. In conclusion, these questions aim to determine the popularity of these practices among young adults. Follow-up interviews reflected reconstructed dialogue as participants were asked to recall specific incidents that exemplified a given politeness practice.

\section{Results}

As perhaps is to be expected, most participants utilized all the politeness resources. However, the element of choice can be perceived in their motivation for employing individual resources and with whom and in which context. Due to space limitations, some practices are exemplified more than others.

\section{Dar su lugar}

Of the 32 respondents in the study, 26 practise dar su lugar (recognise others' social status):

Use of dar su lugar (recognise social status) in constructing interpersonal relationships

Table 1

\begin{tabular}{|c|c|c|c|c|}
\hline $\begin{array}{c}\text { Relational } \\
\text { practice }\end{array}$ & $\begin{array}{c}\text { Adherence to } \\
\text { practice }\end{array}$ & Relational focus & Focus of practice & Context \\
\hline Dar su lugar & 26 & Self: 5 & Everyone: 6 & $\begin{array}{c}\text { Everywhere: } 9 \\
\text { Others: } 6\end{array}$ \\
& & Family: 16 & Home: 4 \\
& & & $\begin{array}{l}\text { Friends: } 5 \\
\text { Co-workers: } 8 \\
\text { Socially: } 10\end{array}$ & $\begin{array}{c}\text { Work: } 6 \\
\text { Social: } 13\end{array}$ \\
\hline
\end{tabular}

The main motivation (15 replies) was social consideration of others in order to show respect and hierarchy since every person deserves to be treated as what they are (MP8) and to show politeness because of cultural tradition (MP25). Participants asserted that dar su lugar is mainly practised in the family (16 replies) and to some extent at work (8 replies). This finding reflects the importance in Mexican politeness practices of recognising hierarchy and status both in the family and at work. While practised on an everyday basis, it is particularly prevalent in social events where interlocutors are sensitive to the status of others. Therefore, dar su lugar can be seen as a semi-private display of politeness and is not especially evident with friends or in everyday life.

The enactment of dar su lugar can be seen through everyday practices such as recognising addresses' professional status e.g. the public use of titles such as arquitecto (architect) and ingeniero (engineer) before their last name or acknowledging educational achievement by addressing hearers as licenciado(a) if they hold a B.A. and especially if it is a law degree. 


\section{Mostrar respeto}

With regards to mostrar respeto (show respect), all the respondents said that they engaged in this practice:

Table 2

Use of mostrar respeto (to show respect) in constructing interpersonal relationships

\begin{tabular}{|c|c|c|c|c|}
\hline $\begin{array}{c}\text { Relational } \\
\text { practice }\end{array}$ & $\begin{array}{c}\text { Adherence to } \\
\text { practice }\end{array}$ & $\begin{array}{c}\text { Relational } \\
\text { focus }\end{array}$ & Focus of practice & Context \\
\hline Mostrar respeto & 32 & Self: 12 & Everyone: 10 & Everywhere: 14 \\
& & Others: 9 & Family: 9 & Home: 5 \\
& & Society: 11 & Friends: 6 & Work: 14 \\
& & & Co-workers: 13 & Social: 12 \\
& & & Socially: 15 & \\
\hline
\end{tabular}

Respondents were divided as to why they express respect. with 12 participants saying that it was for reciprocal reasons: I do it because I expect respect from others too (MP4), I like to be respected (MP21) and I treat people the way I wish I was treated (MP29). In second place were societal reasons for showing respect: To show hierarchy between old people and young people (MP2), to build feelings of wellbeing (MP6) and to show education (MP27). Results show that it is a widespread public practice which aims to reinforce societal relations in terms of social harmony, comity and responsiveness.

In the Mexican context, mostrar respeto is an everyday practice which recognises age, social status and professional standing. So, for instance, Karla was sitting on as bus with her sister, Carolina, when an elderly lady got on and Carolina offer her seat with ¿Gusta sentarse? (Would you like to sit down?). Whilst Carolina's action may be interpreted as simple good manners, her language usage reveals a deeper level of Spanish-language respect (see, for instance, FélixBrasdefer (2008), Fitch (2007) and Mugford (2011). Besides using the respectful usted form, she employed the invitational gustar which carries the implied meaning of hopefully being pleasing to the addressee. Therefore, the simple use of two words was enough to recognise the elderly lady's societal status.

\section{Hacer el bien}

When it comes to hacer el bien (help others without seeking reciprocal action), only one respondent said that they did not engage in this practice:

Use of hacer el bien (to help others) in constructing interpersonal relationships

\begin{tabular}{|c|c|c|c|c|}
\hline $\begin{array}{c}\text { Relational } \\
\text { practice }\end{array}$ & $\begin{array}{c}\text { Adherence to } \\
\text { practice }\end{array}$ & $\begin{array}{c}\text { Relational } \\
\text { focus }\end{array}$ & Focus of practice & Context \\
\hline Hacer el bien & 31 & Self: 18 & Everyone: 14 & Everywhere: 18 \\
& & Others: 6 & Family: 8 & Home: 2 \\
& & Society: 7 & Friends: 10 & Work: 7 \\
& & & Co-workers: 7 & Social: 10 \\
\hline
\end{tabular}


Results indicate that although the relational practice is defined as being generous and giving, the majority of interactants, (18 replies), engaged in this practice for self-oriented and reciprocal reasons: I feel good myself (MP 21), well in my opinion, if I do good I will receive good (MP 23) and to have a clear conscience by conforming to established moral standards (MP32). Whilst well established as a common social practice and performed in public contexts, the rationale seemed to be especially focused on the self.

Hacer el bien means doing the right thing in interpersonal and transactional relationships. For instance, in the following incident, recounted by Fabiola, office recruitment staff in the human resources department in the company where she works had received new prepaid cards with which to buy groceries. However, they went to see their manager, Fabiola, to report that they had been paid twice: on both new and old pre-paid cards. She narrates the incident in the form of reconstructed dialogue:

Sara: $\quad$ Fabiola, depositaron doble en la tarjeta de vales. O sea, tengo dinero en las dos tarjetas.

Fabiola: ¿En serio? Déjame revisar si en la mía también.

Sara: Sólo quiero saber cuál es la buena.

Fabiola: La nueva tarjeta, la anterior fue un error.

Sara: $\quad$ Va, Gracias.

Minutos después entraron los 4 reclutadores y entregaron sus tarjetas de vales viejas.

Sara: $\quad$ Les dije que te las dejáramos, porque se puede hacer mal uso de esas tarjetas y mejor te las dejamos aquí. Ya avisamos a nuestros compañeros y amigos que no las vayan a usar.

Translation:

Sara: $\quad$ Fabiola, they deposited money in both voucher cards. I mean, I have money on both cards.

Fabiola: Seriously? Let me check and see if it is the same with mine as well.

Sara: $\quad$ I just want to know which is right one.

Fabiola: The new card, the old one is a mistake.

Sara: Ok. Thank you.

Minutes later the 4 recruiters returned and handed in their old pre-paid cards.

Sara: $\quad$ I told them to leave them, because you can misuse those cards and we better leave them here. We already warned our colleagues and friends not to use them.

Whilst the incident can be seen, on one level, as an act of honesty, the employees' actions and language reveal underlying relational practices. Sara is not seeking recognition or praise but clarification: Sólo quiero saber cuál es la buena. (I just want to know which is the right one). There is no hint of her trying to take advantage of the situation. Beside handing in the old cards without being asked to 
do so, the employees went further and asked other colleagues not to use the cards. Her actions are aimed at rectifying the situation: mejor te las dejamos aqui (we better leave them here).

\section{Ser servicial}

With respect to ser servicial (cater to others' needs), only four participants said that they did not engage in the practice:

Table 4

Use of ser servicial (cater to others' needs) in constructing interpersonal relationships

\begin{tabular}{|c|c|c|c|c|}
\hline $\begin{array}{c}\text { Relational } \\
\text { practice }\end{array}$ & $\begin{array}{c}\text { Adherence to } \\
\text { practice }\end{array}$ & Relational focus & Focus of practice & Context \\
\hline Ser servicial & 28 & Self: 16 & Everyone: 6 & Everywhere: 8 \\
& & Others: 10 & Family: 16 & Home: 9 \\
& & Society: 2 & Friends: 11 & Work: 13 \\
& & & Co-workers: 11 & Social: 13 \\
\hline
\end{tabular}

Similar to hacer el bien, the practice is focused on both the self and reciprocity as 16 interactants gave these reasons as their prime motivation: To show others that I was well raised (MP 3), Because I look ahead, maybe one day I'll need help with something and I would like to count on someone (MP8) and I like to feel helpful (MP13). However, it is important to recognise that many participants claim to be servicial for interactional reasons: to help others (MP5) and people might need help, and also, it's better if more people finish a task all together (MP19). Rather than being a widely practiced social phenomenon, it seems to be mostly employed with family, co-workers and friends and seen in the home, at work and in social events. Similar to mostrar respeto, it can be seen in terms of promoting social harmony, comity and responsiveness.

Ser servicial (to cater to others' needs) can be seen in everyday expressions in Mexican Spanish such as mande (literally meaning 'command me'), a sus ordenes (at your service) and un servidor (literally meaning 'a servant', but used in a thirdperson way to refer to oneself). The act of being servicial often means completely focusing on others' needs as seen in the following incident recalled by Alberto, a schoolteacher:

Two mothers were are a school party, making sure everything was being taken care of. At the moment of serving the food, there were some waiters, but they [the mothers] were also helping to serve the food. They were asking if we needed something additional to what we were offered. Since I had been in contact with one of them, she approached me and asked me how I was doing and if I needed anything else at that moment.

Hola maestro, ¿cómo está? Espero que le esté gustando todo esto, la señora Rodríguez y yo quisimos venir a ayudar a organizar el evento para ustedes. ¿Gusta que le traiga algo más? 
(Hello teacher, how are you? I hope you like all this, Mrs. Rodríguez and I wanted to come to help organize the event for you. Would you like something else to be brought?)

The mothers adopted the role of servers and their only concern was the smooth running of event. Their submissiveness is conveyed through language such as Espero que le esté gustando todo esto (I hope you like all this) and the use of the third person address form as in ¿cómo está? (how are you?). This incident reveals that ser servicial is not just a matter of being deferential to those in authority but to be willing to cater to the needs of others over a wide range of contexts.

\section{Acomedirse}

When asked if they engaged in acomedirse (to be ready and willing to help), only 25 respondents said that they followed this practice:

Use of acomedirse (ready/willing to help) in constructing interpersonal relationships

\begin{tabular}{|c|c|c|c|c|}
\hline $\begin{array}{c}\text { Relational } \\
\text { practice }\end{array}$ & $\begin{array}{c}\text { Adherence to } \\
\text { practice }\end{array}$ & Relational focus & Focus of practice & Context \\
\hline Acomedirse & 25 & Self: 12 & Everyone: 5 & Everywhere: 6 \\
& & Others: 8 & Family: 18 & Home: 10 \\
& & Society: 5 & Friends: 10 & Work: 9 \\
& & & Co-workers: 10 & Social: 11 \\
& & & Socially: 5 & \\
\hline
\end{tabular}

Respondents were divided as to why they engaged in this practice, although most gave reciprocity as the main reason: Again you never know when you're going to need someone's help (MP6), To help people and to let people know that I'm not a lazy person (MP21) and I do it so it returns to me later in the future (MP31). However, other interactants engage in acomedirse for much more social reasons: just to help others if they're struggling with something in particular (MP19) and cause if you can make someone's job or activity easier or you know how something is done and can do it, why wouldn't you? (MP20). Results indicate that it is an extremely public practice performed throughout society and over a wide variety of social contexts.

Acomedirse (to be ready and willing to help) is often carried out surreptitiously and without fanfare as can be seen in the following example related by Sara.

On December 25, Berenice, took a male friend to her grandparents' house for Christmas lunch and during the meal the friend was very polite and talking all the time. Grandad said, Hey Berenice you said you were going to bring a friend not a refugee: "He eats like an orphan". Everyone laughed. The guest said, the food was delicious and there was no way that he couldn't eat so much. When they finished eating and they remained at the table. He went to the bathroom and when he returned, he went straight to do the dishes. No one noticed until the grandmother went to the kitchen, saw him and said: 
Abuela: ¿Qué haces?

Invitado: $\quad$ En mi casa me enseñaron a lavar los trastes y lavé los tras-

tes de todos.

Translation:

Grandmother: What are you doing?

Guest: At home I was taught to do the dishes and I have washed everyone's

dishes.

The guest had helped out by doing the washing-up without the hosts being aware. The act of acomedirse demonstrates how interactants will help out in surreptitious and unnoticed ways without wanting to seek any recognition.

\section{Mostrar confianza}

In terms of mostrar confianza (demonstrate closeness, certainty and trust), 28 respondents said that performed this practice:

Table 6

Use of mostrar confianza (show closeness) in constructing interpersonal relationships

\begin{tabular}{|c|c|c|c|c|}
\hline $\begin{array}{c}\text { Relational } \\
\text { practice }\end{array}$ & $\begin{array}{c}\text { Adherence to } \\
\text { practice }\end{array}$ & Relational focus & Focus of practice & Context \\
\hline Mostrar & 28 & Self: 4 & Everyone: 3 & Everywhere: 5 \\
confianza & & Others: 22 & Family: 19 & Home: 13 \\
& & Society: 2 & Friends: 21 & Work: 7 \\
& & & $\begin{array}{c}\text { Co-workers: } 5 \\
\text { Socially: } 2\end{array}$ & Social: 15 \\
\hline
\end{tabular}

In mostrar confianza, the main and overwhelming motivation was concern for others: I do it because I like the others to feel comfortable (MP1), to show others that they are in a comfortable atmosphere (MP3) and to build trust and happy and healthy relationships (MP6). This practice does appear to be more limited to family and friends and carried out in social contexts and especially at home. Therefore, it might be considered to be a more private expression of relational work which aims to reinforce solidarity, supportiveness and closeness.

To demonstrate confianza (i.e. closeness), interactants will often display a degree of openness regarding their personal lives which in other cultures would only take place after a long period of friendship if at all. The level of confianza emerges through interactants' willingness to engage in cotorreo (chit-chat), chisme (gossip) and albures (puns with double meanings).

\section{Mostrar cariño}

When asked to focus on mostrar cariño (display fondness, affection and warmth towards others), only four participants said that they did not engage in this practice: 
Use of mostrar cariño (display affection) in constructing interpersonal relationships

\begin{tabular}{|c|c|c|c|c|}
\hline $\begin{array}{c}\text { Relational } \\
\text { practice }\end{array}$ & $\begin{array}{c}\text { Adherence to } \\
\text { practice }\end{array}$ & Relational focus & Focus of practice & Context \\
\hline Mostrar cariño & 28 & Self: 12 & Everyone: 0 & Everywhere: 3 \\
& & Others: 16 & Family: 28 & Home: 18 \\
& & Society: 0 & Friends: 25 & Work: 6 \\
& & & $\begin{array}{c}\text { Co-workers: } 1 \\
\text { Socially: } 0\end{array}$ & Social: 12 \\
\hline
\end{tabular}

The phenomenon of mostrar cariño can be seen as a private and interactional phenomenon that responds to personal and relational needs. On a personal level, interactants said they used it to show I care for the person or thing (MP26), to show someone that you love them (MP28) and it feels nice to be nice and show it (MP 29). Meanwhile, on a more interactional level, mostrar cariño can make the other person know he's special (MP6), show a level of closeness and care and even love in a relationship (MP14) and build a relation (MP15). Consequently, this practice is focused mainly on friends and family, especially at home and on social occasions. Similar to mostrar confianza, mostrar cariño also furthers solidarity, supportiveness and closeness.

The demonstration of cariño on an everyday basis can be seen through the widespread use of diminutives to express endearment e.g. abuela (grandmother) becomes abuelita and mamá (mother) can become mamita. Meanwhile nicknames are also a common way of showing endearment e.g. el güero (light-haired) and el chino (curly-haired).

\section{Echar carrilla}

With regards to echar carrilla (good-natured teasing), 25 respondents said that they engage in this practice:

Table 8

Use of echar carrilla (good-natured teasing) in constructing interpersonal relationships

\begin{tabular}{|c|c|c|c|c|}
\hline $\begin{array}{c}\text { Relational } \\
\text { practice }\end{array}$ & $\begin{array}{c}\text { Adherence to } \\
\text { practice }\end{array}$ & Relational focus & Focus of practice & Context \\
\hline Echar carrilla & 25 & Self: 10 & Everyone: 1 & Everywhere: 4 \\
& & Others: 13 & Family: 17 & Home: 8 \\
& & Society: 2 & Friends: 23 & Work: 7 \\
& & & $\begin{array}{c}\text { Co-workers: } 9 \\
\text { Socially: } 0\end{array}$ & Social: 11 \\
\hline
\end{tabular}

The practice of echar carrilla is mainly performed for interactional reasons although there is a strong personal component. Among the interactional reasons were: To laugh at ourselves and have a good time (MP6), to have fun and to form a closer relationship (MP13) and to have fun and laugh or a while, it's also a way to showing when you feel comfortable enough to joke around ((MP23). However, personal reasons seem to be equally important: to laugh, to have a good time 
(MP12), to show some "humour" (MP 25) and have some fun with people you like having around (MP28). At the same time, echar carrilla is a semi-private practice mainly performed at home, socially and sometimes at work. When successful, echar carrilla can be seen to strengthen camaraderie, commonality and interpersonal cohesion.

Echar carrilla (good-natured teasing) can be interpreted as harmless language play as interactants engage in relational ribbing. This can be seen in the following incident where Carla remembered when one of her friends, Dafne was echando carrilla with Edna who was in a long-distance romantic relationship. Dafne said playfully ¡Eehhh le gustas! (Eeee you like him!), Es guapo (He is good-looking), Van a hacer una pareja bonita (You guys will make a really nice couple) and iTraelo aqui! (Bring him here!). Carla sees this gentle ribbing as polite and said the friend was only "echando romantic carrilla" (engaging in romantic teasing). This serves to reinforce the relationship between Dafne and Enda and Dafne is demonstrating explicit approval of the boyfriend.

Vacilar

With respect to vacilar (joking/pulling someone's leg). 24 respondents engaged in this practice:

Table 9

Use of vacilar (joking/pulling someone's leg) in constructing interpersonal relationships

\begin{tabular}{|c|c|c|c|c|}
\hline $\begin{array}{c}\text { Relational } \\
\text { practice }\end{array}$ & $\begin{array}{c}\text { Adherence to } \\
\text { practice }\end{array}$ & Relational focus & Focus of practice & Context \\
\hline Vacilar & 24 & Self: 15 & Everyone: 1 & Everywhere: 6 \\
& & Others: 9 & Family: 17 & Home: 8 \\
& & Society: 0 & Friends: 20 & Work: 9 \\
& & & $\begin{array}{c}\text { Co-workers: } 8 \\
\text { Socially: } 2\end{array}$ & Social: 10 \\
& & & & \\
\hline
\end{tabular}

In comparison to echar carrilla, the practice of vacilar is more self-focused as respondents gave the following motivations: because I am in a good mood ... I wanna joke or because the other person did it to me before (MP7), sometimes I use (in moderation) it to get relax with people around me, as an icebreaker (MP21) and to have fun with people you like having around (MP28). However, there is an interactional dimension: To show closeness have fun (MP11), to show the level of closeness and informality in a relationship (MP14) and to counter attack a joke or to make everybody laugh (MP26). Similar to echar carrilla, vacilar is a semiprivate practice mainly performed with friends and at social events. Similar to echar carrilla, vacilar can also bolster camaraderie, commonality and interpersonal cohesion.

Vacilar (leg-pulling) can involve making fun of others and of oneself as seen in this example provided by Sandra. 
This past weekend my dad ran into a neighbour in the grocery store. My dad then gave him a ride back to his house because he was carrying a lot of many bags. On the way, the neighbour said, Fijese, nomás venía por una cosa y vea con todo lo que sali (Can you believe it, I just came for one thing and look at everything that I came away with). To this my dad replied, Yo también, cómo ve, ando de mandilón (Me too, what do you think, I just do what my wife tells me to do).

Sandra says that her father was just joking in calling himself un mandilón and that he was being ordered about. However, the self-deprecation potentially creates a bond between the two men as they can see themselves in the same situation.

In summary, the results indicate that, whilst most participants employ the full range of relational practices, they do not do so for the same reasons. I have declined to show a final graphic to jointly show the responses for all the categories under analysis because this may give the false impression that these politeness practices represent alternative strategies. Rationale and context may vary between interactants and therefore represent a much more personalised motivation and choice behind the use of relational resources which reflect social harmony, comity, solidarity, supportiveness, camaraderie and commonality.

\section{Discussion}

Results from the research indicate that respondents view the enactment of politeness from both individual, interactional and societal viewpoints, as they seek to construct interpersonal relationships. Spanish-language first- and second-wave approaches provide useful insights into Mexican relational talk, especially in terms of strategic and ritual politeness (first wave) and valorising and discursive politeness (second wave). However, a third-wave approach may be more productive in trying to theorise politeness practises and extend understanding to other communicative contexts.

Spanish-language first-wave approaches that focus on strategic politeness (Bernal 2018: 133) help understand the reciprocal motivation of interactants who enact politeness strategies as part of a quid pro quo, especially with regards to mostrar respeto, hacer el bien, ser servicial and acomedirse. For instance, with mostrar respeto (show respect), 12 participants asserted that they demonstrated respect because they expected to be respected in turn. This also seemed to be the case with hacer el bien (help others without seeking reciprocal action), where 18 respondents said that they expected to be repaid in kind in the future. A similar situation can be seen with ser servicial (cater to others' needs), where 16 participants reported that it portrays them in a positive light, and they hope to be helped in a similar way in the future. A similar situation can be found in acomedirse (ready and willing to help), where 12 participants said that they expected to be helped out in the future. At the same time, politeness strategies also reflect Bravo's (2008) affiliative stance as also seen in interactants' answer to why they mostrar respeto, hacer el bien, ser servicial and acomedirse. Rather than engaging in these 
politeness practices as a way of avoiding face threatening acts (Brown and Levinson 1987), Mexican respondents' answers revealed that they were more focused on developing comity and harmonious and cordial relationships. However, in the category of dar su lugar (recognise others' social status), 15 respondents said that they enact this practice as a way of adhering to cultural and societal norms. Since the use of these strategies tends to reflect the beginning of social and transactional relationships, their strategic use may be due to interactants trying to determine how evolving relationships might further develop and therefore can perhaps be better understood in terms of ritual politeness which 'occurs in meeting situations' (Bernal 2018: 266).

Second-wave discursive approaches reflect valorising politeness (Bernal 2018), as interactants try to enhance and further relationships while showing affiliative appreciation for the ongoing relationship. This can readily be seen in mostrar confianza, mostrar cariño, echar carrilla and vacilar, where politeness patterns and practices are more focused on developing, consolidating and reinforcing relationships. For instance, in mostrar confianza (demonstrate closeness, certainty and trust), 22 respondents said that they engaged in this practice as part of relational work. On the other hand, mostrar cariño (display fondness, affection and warmth towards others) revealed both interactional (16 replies) and personal (12 replies) motivations. The same situation can be seen with echar carrilla (good-natured teasing), which reflects the same practices: interactional (13 replies) and personal (10 replies). On the other hand, vacilar (joking/pulling someone's leg) is more focused on interactants having fun: personal (15 replies) and interactional ( 9 replies).

Whilst the research has identified the possible motivation behind a range of politeness strategies, a deeper understanding can be attained by developing a theoretical framework which explains how social harmony, comity, solidarity, supportiveness, camaraderie and commonality are achieved which seem to go beyond first- and second-wave explanations. At first blush, interactional relationships in Mexican Spanish have a strong transactional element, especially with initial contacts as interactants expect to be acknowledged on a similar basis if they engage in practices such as mostrar respeto, hacer el bien, ser servicial and acomedirse. The results in this study therefore question the perception that Mexican interactants are primarily focused on disinterestedly satisfying the needs of others (as argued by Grinsted 2000). So, while interactants may show genuine interest in recognising the status of others and supporting their wellbeing, they may still expect to be reciprocated in turn. Secondly, Mexican politeness strategies contain a strong emotional dimension (i.e. mostrar confianza and mostrar cariño), as well as a ludic dimension (i.e. echar carrilla and vacilar). More research needs to be conducted into the emotional and ludic dimensions as they represent a much more dynamic and evolving individually motivated nature of politeness which are strongly related to the development, consolidation and even deterioration of a given relationship. 


\section{Conclusion}

An understanding of local politeness practices provides insights into how interpersonal relationships are developed, constructed and maintained as interactants pursue both personal, interpersonal and societal goals within a given community. Politeness patterns and practices need to be studied and analysed as motivated language use and not just in terms of simple relational work. Rather than 'matching linguistic forms with politeness values and assessing their appropriateness' (Ogiermann and Garcés-Conejos Blitvich 2019: 2), this research points to a third-wave approach that matches interactants' perceptions with possible theoretical understandings. Since this investigation focused on middle-class Mexican professionals, future research needs to examine the social dimension to motivation and choice by examining other social groups.

So, whilst relational phenomena such as showing respeto, confianza and cariño (along with camaraderie, afiliación and reciprocidad) need to be further identified, illustrated and exemplified, a greater understanding can be achieved by constructing a theoretical framework around their use as reported by the interactants themselves. This can be achieved by using taped or videotaped data followed by interviewing participants and discussing with them why a certain politeness practice was employed. However, this paper should be seen as an initial attempt to identify practices and identify what the users themselves claim to be doing. In the case of everyday Mexican Spanish politeness practices, these insights highlight how choices and motivations influence interlocutors as they construct, develop and maintain interpersonal and transactional relationships.

(C) Gerrard Mugford, 2020
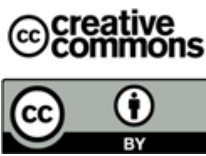

This work is licensed under a Creative Commons Attribution 4.0 International License https://creativecommons.org/licenses/by/4.0/

\section{Appendix}

Do you follow these Mexican relational practices? I would be grateful if you could answer the following questions. All answers will be treated anonymously.

\begin{tabular}{|l|c|c|c|c|}
\hline $\begin{array}{c}\text { Relational } \\
\text { practice }\end{array}$ & $\begin{array}{c}\text { Do you follow } \\
\text { these } \\
\text { practices? } \\
\text { Yes / No }\end{array}$ & $\begin{array}{c}\text { If yes, why } \\
\text { do you use them? } \\
\text { What is their } \\
\text { purpose? }\end{array}$ & $\begin{array}{c}\text { Who do you use } \\
\text { them with? } \\
\text { (e.g. friends, family, } \\
\text { classmates) }\end{array}$ & $\begin{array}{c}\text { Where do you use } \\
\text { them? (e.g. at work, } \\
\text { school, social events) }\end{array}$ \\
\hline Dar su lugar & & & & \\
\hline Mostrar respeto & & & & \\
\hline
\end{tabular}


Gerrard Mugford. Russian Journal of Linguistics. 2020. T. 24. № 1. C. 31-55

\begin{tabular}{|l|l|c|c|c|}
\hline $\begin{array}{c}\text { Relational } \\
\text { practice }\end{array}$ & $\begin{array}{c}\text { Do you follow } \\
\text { these } \\
\text { practices? } \\
\text { Yes / No }\end{array}$ & $\begin{array}{c}\text { If yes, why } \\
\text { do you use them? } \\
\text { What is their } \\
\text { purpose? }\end{array}$ & $\begin{array}{c}\text { Who do you use } \\
\text { them with? } \\
\text { (e.g. friends, family, } \\
\text { classmates) }\end{array}$ & $\begin{array}{c}\text { Where do you use } \\
\text { them? (e.g. at work, } \\
\text { school, social events) }\end{array}$ \\
\hline Hacer bien & & & & \\
\hline Scr servicial & & & & \\
\hline Mostrar confianza & & & & \\
\hline Mostrar cariño & & & & \\
\hline Echar carrilla & & & & \\
\hline Vacilar & & & & \\
\hline
\end{tabular}

\section{REFERENCES}

Arundale, Robert. 2010. Constituting face in conversation: face, facework, and interactional achievement, Journal of Pragmatics 42(8). 2078-2105.

Bayraktaroğlu, Arin. 1991. Politeness and interactional imbalance. International Journal of the Sociology of Language 92. 5-34.

Bayraktaroğlu, Arin. 2001. Advice-giving in Turkish: "Superiority" or "solidarity"? In Arin Bayraktaroğlu and Maria Sifianou (eds.). Linguistic Politeness Across Boundaries: The case of Greek and Turkish, 177-208. Amsterdam: John Benjamins.

Bernal, Maria. 2018. Teaching sociopragmatics; Face-work, politeness and impoliteness in L2 Spanish colloquial conversation. In Domnita Dumitrescu \& Patricia Lorena Andueza (eds.) L2 Spanish Pragmatics: From Research to Teaching, 131-150. London/New York: Routledge.

Bravo, Diana. 2008. The implications of studying politeness in Spanish-speaking contexts: A discussion. Pragmatics 18 (4). 577-603.

Brown, Penelope \& Stephen Levinson 1987. Politeness: Some Universals in Language Usage. Cambridge: Cambridge University Press.

Culpeper, Jonathan. 2011a. Im/politeness and im/politeness. In Gisle Andersen and Karen Aijmer (eds.) Pragmatics of Society, 393 - 438. Berlin/Boston: De Gruyter Mouton.

Culpeper Jonathan. 2011b. Impoliteness: Using Language to Cause Offence, Cambridge: Cambridge University Press.

Curcó, Carmen. 2007. Positive face, group Face, and affiliation: An overview of politeness studies on Mexican Spanish. In Maria Elena Placencia and Carmen García (eds.) Research on Politeness in the Spanish-Speaking World, 105-120. Mahwah: Laurence Erlbaum.

Curcó, Carmen. 2011. El papel de la imagen positiva en la expresión de la cortesía en México, Conferencia Magistral, Segundo Coloquial Regional del Programa EDICE-México, Universidad Autónoma de Nuevo León. 
Czerwionka, Lori. 2014. Participant perspectives on mitigated interactions: The impact of imposition and uncertainty. Journal of Pragmatics 67. 112-130.

Fant, Lars. 1989. Cultural mismatch in conversation: Spanish and Scandinavian communicative behaviour in negotiation settings. Hermes Journal of Linguistics 3. 247-265.

Félix-Brasdefer, J. César. 2006. Linguistic politeness in Mexico: Refusal strategies among male speakers of Mexican Spanish. Journal of Pragmatics 38 (12). 2158-2187.

Félix-Brasdefer, J. César. 2008. Politeness in Mexico and the United States: A Contrastive Study of the Realization and Perception of Refusals. Amsterdam/Philadelphia: John Benjamins.

Félix-Brasdefer, J. César. 2012. Pragmatic variation by gender in market service encounters in Mexico. In J. César Félix-Brasdefer and Dale Koike (eds.) Pragmatic Variation in First and Second Language Contexts: Methodological Issues, 17-48. Amsterdam / Philadelphia: John Benjamins.

Félix-Brasdefer, J. César \& Gerrard Mugford (forthcoming). Politeness research in the SpanishSpeaking world. In Dale Koike and J. César Félix-Brasdefer (eds.), The Routledge Handbook of Spanish Pragmatics. London/New York: Routledge.

Fernández-Amaya, Lucía. 2019. Disagreement and (im)politeness in a Spanish family members' WhatsApp group. Russian Journal of Linguistics 23 (4). 1065-1087. DOI: 10.22363/2687-0088-2019-23-4-1065-1087

Fitch, Kristine. 2007. Two politeness dilemmas in Colombian interpersonal ideology In Maria Elena Placencia \& Carmen Garcia (eds.), Research on Politeness in the Spanish-Speaking World. 245-260. Mahwah, N.J.: Lawrence Erlbaum Associates.

Fraser, Bruce. 1990. Perspectives on politeness, Journal of Pragmatics 14. 219-236.

Garcia, Carmen. 2008. Different realizations of solidarity politeness: Comparing Venezuelan and Argentinean invitations. In Klaus P. Schneider and Anne Barron (eds.) Variational Pragmatics: A Focus on Regional Varieties in Pluricentric Languages. Pragmatics Beyond New Series 178, 269-305.Amsterdam, The Netherlands: John Benjamins.

Goffman, Erving. 1967. Interactional Ritual: Essays on Face-to-Face Behaviour, New York: Double Day Books.

Grinsted, Annette. 2000. Categorías gramaticales y pragmática en el español mexicano y el peninsular, Moderna Sprak 94 (2). 205-213,

Grundy, Peter. 2000. Doing Pragmatics, London: Arnold.

Halliday, Michael A. K. 1997/1973. Language in a social perspective. In Nikolas Coupland \& Adam Jaworski (eds.) Sociolinguistics: A Reader and Coursebook, 31-38. Basingstoke: Macmillan.

Haugh, Michael. 2007. The discursive challenge to politeness research: An interactional alternative. Journal of Politeness Research 3 (2). 295-317.

Hernandez-López, M de la O. 2019. Relational work in Airbnb reviews, Russian Journal of Linguistics 23 (4). 1088-1108. DOI: 10.22363/2687-0088-2019-23-4-1088-1108

Hickey, Leo. 2004. Politeness in Spain. In Leo Hickey \& Miranda Stewart (eds.) Politeness in Europe, 317-330. Clevedon: Multilingual Matters.

Jucker, Andreas H. \& Larssyn Staley. 2017. (Im)politeness and developments in methodology.

In Jonathan Culpeper, Michael Haugh \& Daniel Z, Kádár (eds.) The Palgrave Handbook of Linguistic (Im)politeness, 403-429. Palgrave Macmillan United Kingdom.

Kádar, Daniel Z. 2017. Politeness, Im/politeness and Ritual: Maintaining the Moral Order in Interpersonal Interaction, Cambridge: Cambridge University Press.

Kádár, Dániel Z. \& Michael Haugh. 2013. Understanding Im/politeness, Cambridge: Cambridge University Press. 
Larina, Tatiana. 2015. Culture-Specific Communicative Styles as a Framework for Interpreting Linguistic and Cultural Idiosyncrasies. International Review of Pragmatics 7 (2). $195-$ 215.

Leech, Geoffrey.1983. Principles of Pragmatics. London: Longman.

Locher, Miriam A. \& Tatiana V. Larina. 2019. Introduction to politeness and impoliteness research in global contexts. Russian Journal of Linguistics 23 (4). 873-903. DOI: 10.22363/2687-0088-2019-23-4-873-903

Maíz Arévalo, Carmen. 2018. «Sólo un poquito»: El uso y funciones del diminutivo en español peninsular en dos grupos de Facebook. Círculo de Lingüística Aplicada a la Comunicación (CLAC). Volumen monográfico 'La atenuación en los discursos digitales en español', 73. 33- 52 .

Márquez-Reiter, Rosina. 2019. Navigating commercial constraints in a service call. In Pilar Garcés-Conejos Blitvich, Lucia Fernández-Amaya \& María de la O Hernández-López (eds.) Technology Mediated Service Encounters, 121-144. Amsterdam/Philadelphia: John Benjamins.

Márquez Reiter Rosina \& Maria Elena Placencia. 2005. Spanish Pragmatics. Basingstoke: Palgrave: Macmillan.

Mills, Sara. 2017. English Politeness and Class, Cambridge: Cambridge University Press.

Mugford, Gerrard. 2011. That's not very polite! Discursive struggle and situated politeness in the Mexican English-language classroom. In Situated Politeness. Edited by Bethan L. Davies, Michael Haugh and Andrew John Merrison, 53-72, London/New York: Continuum.

Mugford, Gerrard. 2013. Foreign-language users confronting anti-normative politeness in a Mexican university. Intercultural Pragmatics, 10. 101-130.

Mugford, Gerrard. 2014. Examining first-order localised politeness: Mexican positive impoliteness practices, Journal of Language Aggression and Conflict 2 (1). 99-126.

Mugford, Gerrard \& María Luisa Arias Moreno. 2017. La refutación de la percepción de descortesía en los adultos jóvenes: la detección de prácticas interpersonales de tú/usted en México, Discurso \& Sociedad 11 (1). 134-162.

Ogiermann, Eva \& Pilar Garcés-Conejos Blitvich. 2019. Im/politeness between the Analyst and Participant Perspectives: An Overview of the Field. In Eva Ogiermann \& Pilar GarcésConejos Blitvich (eds.), From Speech Acts to Lay Understandings of Politeness, 1-24. Cambridge: Cambridge University Press.

Placencia, Maria Elena. 2019. Responding to bargaining moves in a digital era: Refusals of offers on Mercado Libre Ecuador. In Pilar Garcés-Conejos Blitvich, Lucia FernándezAmaya \& María de la O Hernández-López (eds.), Technology Mediated Service Encounters, 173-197. Amsterdam/Philadelphia: John Benjamins.

Placencia, María Elena \& Carmen García (eds.). 2007. Research on Politeness in the SpanishSpeaking World. Mahwah, N.J.: Lawrence Erlbaum Associates.

Scollon Ron \& Suzanne Scollon. 1995. Intercultural Communication, Oxford: Blackwell.

Sifianou, Maria. 1995. Do we need to be silent to be extremely polite? Silence and FTAs. International Journal of Applied Linguistics 5 (1). 95-110.

Spencer-Oatey, Helen (ed.) 2008a. Culturally Speaking: Managing Rapport through Talk across Culture. London: Continuum.

Spencer-Oatey, Helen. 2008b. Face, (Im)Politeness and Rapport. In Helen Spencer-Oatey (ed.) Culturally Speaking: Managing Rapport through Talk across Culture, 12-47. London: Continuum. 
Terkourafi, Marina \& Daniel Z. Kádár. 2017. Convention and Ritual (Im)politeness. In Jonathan Culpeper, Michael Haugh \& Daniel Z, Kádár (eds.) The Palgrave Handbook of Linguistic (Im)politeness, 171-195. Palgrave Macmillan United Kingdom.

Watts Richard J. 2003. Politeness. Cambridge: Cambridge University Press.

Article history:

Received: 18 June 2019

Revised: 25 August 2019

Accepted: 19 November 2019

\section{История статьи:}

Дата поступления в редакцию: 18 июня 2019

Дата принятия к печати: 19 ноября 2019

\section{Bionote:}

GERRARD MUGFORD is a lecturer in pragmatics, discourse analysis and sociolinguistics at la Universidad de Guadalajara, Guadalajara, Mexico. His current research interests include $\mathrm{im} /$ politeness, foreign-language interpersonal language use and critical pedagogy. He has published articles and book chapters on politeness, impoliteness, anticortesía, phatic communion and lexical studies in Mexico, the United States, the United Kingdom, Canada, Spain and Colombia. His recent book is Addressing Difficult Situations in Foreign-Language Learning: Confusion, Impoliteness, and Hostility (Routledge, 2018).

\section{Contact information:}

E-mail: gemugford1@gmail.com

Address: Guanajuato \#1045, Col. Alcalde Barranquitas 44260. Guadalajara, Jalisco, México.

ORCID: 0000-0001-9828-7801

\section{Сведения об авторе:}

ГЕРАРД МАГФОРД - доцент Гвадалахарского университета (Гвадалахара, Мексика), специалист в области прагматики, дискурс-анализа и социолингвистики. Научные интересы: не/вежливость, использование иностранного языка в межличностных отношениях и критическая педагогика. Автор ряда статей и глав монографий, посвященных проблемам не/вежливости, фатическому общению и лексикологии, опубликованных в Мексике, США, Великобритании, Канаде, Испании и Колумбии. В издательстве Routledge в 2018 г. вышла его книга Addressing Difficult Situations in Foreign-Language Learning: Confusion, Impoliteness, and Hostility.

\section{Контактная информация:}

E-mail: gemugford1@gmail.com

Address: Guanajuato \#1045, Col. Alcalde Barranquitas 44260. Guadalajara, Jalisco, México. ORCID: 0000-0001-9828-7801 